\title{
MANAJEMEN PENGORGANISASIAN PROGRAM KURSUS MARKAZ BAHASA ARAB DARUL LUGHAH WADDIRASAT ISLAMIYAH
}

\author{
Islahel Umam, Moh. Hasin, Zakiyah Arifa \\ Universitas Islam Negeri (UIN) Maulana Malik Ibrahim Malang \\ Jl Gajayana No.50, Dinoyo, Kec. Lowokwaru, Malang, Jawa Timur 65144 \\ e-mail: islah.umam99@gmail.com
}

\begin{abstract}
This research discusses about: 1) organizing management in Arabic center DLWI Pamekasan, 2) problems in organizing management at Arabic center institute DLWI Pamekasan. This is a descriptive qualitative research. The data are collected by interviews and documentation. Then the data were analyzed in three steps, 1) data reduction, 2) data presentation, 3) drawing conclusions / verification. The results of this research shows that the organizing management Arabic language center DLWI Pamekasan arranged the division of duties and authority of members of the organization based on structure namely linear organization. Authority is not given to just anyone but through a strict qualification system.
\end{abstract}

Keywords: Organizing, Arabic Center Program, Arabic Language

\begin{abstract}
Abstrak
Penelitian ini membahas mengenai: 1) Manajemen pengorganisasian kursus yang terdapat dalam Markaz Bahasa Arab DLWI di Palengaan Pamekasan, 2) Permasalahan dalam manajemen pengorganisasian dalam Markaz Bahasa Arab Darul Lughah Wadidirasat al-Islamiyah (DLWI) di Palengaan Pamekasan. Penelitian ini menggunakan metode penelitian dengan pendekatan kualitatif bersifat deskriptif. Pengumpulan data dilakukan dengan teknik wawancara dan dokumentasi. Setelah data terkumpul, dilakukan analisis data dengan: 1) reduksi data, 2) penyajian data, 3) penarikan kesimpulan/verifikasi dari penelitian ini dapat disimpulkan bahwa tipe organisasi yang dianut oleh PP. DLWI adalah tipe organisasi lini, penyerahan wewenang dan tanggung jawab dilakukan langsung oleh manajer secara langsung serta pengelompokan program berdasarkan tingkatan masing-masing peserta didik.
\end{abstract}

Kata Kunci: Manajemen Pengorganisasian, Program Markaz, Bahasa Arab 


\section{A. Pendahuluan}

Dalam diskursus dunia pendidikan terdapat manajemen yang memiliki fungsi sebagai komponen krusial dalam menjalankan setiap aktivitas rotasi dalam pendidikan. Manajemen mempunyai beberapa fungsi pokok, yaitu; Perencanaan (Planning), Pengorganisasian (Organizing), Pemimpinan (Leading), dan Pengawasan (Controlling). ${ }^{1}$ Berdasarkan uraian tersebut, manajemen dapat dipahami sebagai sebuah proses merencana, mengorganisasi, memimpin, dan mengendalikan upaya organisasi dengan segala aspek dan faktor agar segala bentuk tujuan dalam organisasi dapat tercapai secara efektif dan efisien sebagaimana yang diharapkan.

Sudah menjadi keniscayaan bahwa dalam satu lembaga pendidikan baik yang bersifat formal atau non-formal terdapat fungsi perencanaan yang tidak mungkin pernah berhasil tanpa adanya fungsi pengorganisasian, dan dapat dipstikan bahwa fungsi pengorganisasian tidak akan pernah goal tanpa adanya sumber daya manusia yang memadia sebagai pelaku dan pelaksannaya. Kata pengorganisasian yang dalam bahasa Inggris dikenal dengan "Organizing” merupakan metamorfosis dari kata organize yang bermakna membentuk, membuat atau mrancang sebuah struktur dengan segmen-segmen yang dipadu-padankan sedemikian rupa sehingga antara satu dengan lainnya memiliki satu hubungan yang tak dapat dipisahkan. ${ }^{2}$

Oleh sebab itu, menjadi satu keharusan bahwa eksistensi manajeman pengorganisasian pada suatu lembaga pendidikan agar dapat memutuskan dan menetapkan berbagai tugas yang dipandang urgen untuk diterapkan dan siapa saja yang akan mengambil keputusan tentang tugas-tugas tersebut sehingga terwujud pembagian kerja yang struktural dalam suatu sistem garis koordinasi.

\footnotetext{
${ }^{1}$ Nanang Fattah, Landasan Manajemen Pendidikan (Bandung: Remaja Rosdakarya, 2004), h. 57.

${ }^{2}$ Malayu S.P. Hasibuan, Manajemen: Dasar, Pengertian, dan Masalah (Jakarta: CV. Haji Mas Agung, 1990), h. 3.
} 
Markaz bahasa merupakan lembaga pelatihan yang termasuk dalam jenis lembaga pendidikan nonformal. markaz bahasa yaitu suatu wahana pembelajaran bahasa yang mempertajam skill bahasa seseorang. Dengan berbagai model, strategi, materi dan siklus belajar-mengajar yang berorientasi mengasah kemampuan dan kecakapan dalam berbahasa secara kreatif, inovatif dan efektif.

Salah satu markaz bahasa yang masyhur di Indonesia berada di kecamatan Palengaan kabupaten Pamekasan terletak di pulau Madura. Kabupaten Pamekasan banyak menarik minat orang-orang untuk mempelajari keterampilan bahasa bukan hanya dari Indonesia saja. Seiring berjalannya waktu peminat orang-orang untuk belajar keterampilan bahasa bukan bahasa Inggris saja melainkan untuk belajar bahasa Arab. ${ }^{3}$

Terdapat beberapa Markaz Bahasa Arab yang berkembang di Pamekasan salah satunya adalah markaz bahasa Arab DLWI. Bila manajemen pengorganisasian menjadi syarat mutlak dalam mengelola atau mengoranisasi pada suatu lembaga formal atau non formal Maka, otomatis markaz Bahasa Arab DLWI memiliki peran krusial dalam sistem keorganisasiannya.

Berangkat dari asumsi tersebut, markaz Bahasa Arab DLWI memiliki lembaga pengoorganisasian yang cukup menarik untuk diamati dan diteliti sebagai wahana mengembangkan keterampilan berbahasa Arab. Beberepa kelebihan dan kekurangan dapat diketahui secara jelas dengan meneliti secara detil manajemen pengorganisasian dalam markaz Bahasa Arab DLWI.

Berdasarkan latar belakang di atas, maka dapat dirumuskan masalah sebagai berikut: Bagaimana manajemen pengorganisasian program kursus bahasa Arab di markaz bahasa Arab Darul Lughag Waddirasat Islamiyah?

\footnotetext{
${ }^{3}$ Bisa dilihat dalam Asep Muhammad Saepul Islam, "Faktor Demotivasi Pembelajaran Bahasa Arab dalam Perspektif Siswa Madrasah," Arabiyat: Jurnal Pendidikan Bahasa Arab dan Kebahasaaraban Vol. 02, no. 1 (2015): h. 5.
} 


\section{B. Landasan Teori}

\section{Manajemen Pengorganisasian}

\section{a) Pengertian Teoritis Pengorganisasian}

Term pengorganisasian atau Organizing secara etimologi adalah organize yang memiliki makna mengadakan. Adapun secara terminologi adalah suatu struktur dari sub-sub yang diintregasikan, sehingga menciptakan relasi antar individu yang terikat kuat oleh satu sama lain secara keseluruhannya. Organisasi bermakna sebagai sebuah gambaran atau skema yang memiliki gari-garis dan menunjukkan perintah atrau kedudukan anggota serta hubungan antar individu yang telah ditetapkan. ${ }^{4}$

Sedangkan dalam pembacaan Al-Asy'ari pengorganisasian adalah sekelompok individu yang saling bekerjasama untuk melaksanakan kewajiban dan tugas sesuai dengan leveling struktur yang telah ditetapkan. Setiap personal akan menjalankan tugas yang telah disesuaikan dengan kemampuannya disertai dengan wewenang sebagai upaya mencapai tujuan yang telah ditentukan di awal.

Dalam artian, memanfaatkan segala sesuatu pada fungsinya, begitu juga memberdayakan setiap anggota sesuai tugas pokok, dan fungsinya. Dan membangun suatu ikatan antar individu untuk menciptakan kesamaan rasa, kepadanan tujuan, dan kesatuan perilaku yang sinergi dalam rangka meraih cita-cita yang akan dicapai. ${ }^{5}$

Pengorganisasian dapat pula ditafsiri sebagai suatu aktivitas yang dilaksanakan dalam berbagai tugas kecil, menginstruksikan tugas, tanggung jawab, dan wewenang kepada setiap individu sesaui

\footnotetext{
${ }^{4}$ Hasibuan, Manajemen: Dasar, Pengertian, dan Masalah, h.23.

${ }^{5}$ Al-Hawary dan Sayyid Mahmud, Idarah Al-Usus wa Ushul Al-IImiyah (Kairo: Darul Kutub Al-IImiyah, 1976), h. 765.
} 
kemampuan masing-masing, memilih secara seksama dan mengklasifikasikan personal sesuai kadar kemampuan untuk menggapai cita-cita dan tujuan organisasi.

Pada hakekatnya, organisasi mepunya dua orientasi. Pertama, organisasi berorientasi pada suatu lembaga atau kelompok fungsional, seperti; perusahaan, sekolah, dan lembaga pemerintahan ataupun ketatanegaraan. Kedua, merujuk pada suatu aktivitas pengorganisasian, bagaimana suatu kegiatan dapat di-handle, diatur, dan dialokasikan secara konsisten oleh individu, sehingga terwujud sebuah pencapaian tujuan organisasi yang maksimal. Sedangkan organisasi memiliki makna sekumpulan individu dengan sistem sama kerja dan kerja sama untuk meng-goal-kan tujuan kolektif. ${ }^{6}$

Berdasarkan pemaparan tersebut dapat ditarik benang merah bahwa pengorganisasian adalah proses menciptakan, membangun dan mengadakan suatu struktur dari sub-sub yang diintregasikan, sehingga menciptakan relasi kuat antar individu yang saling terikat antara satu dengan yang lain sebagai upaya mencapai tujuan organisasi yang efisien dan maksimal. ${ }^{7}$

\section{b) Proses (Langkah-Langkah) Pengorganisasian}

1) Manager dapat membaca tujuan utama organisasi.

2) Menetapkan dan menentukan serangkaian program kerja organisasi.

3) Mengklasifikasikan program dan kegiatan organisasi

4) Mengintruksikan tugas, tanggung jawab dan wewenang kepada setiap anggota.

\footnotetext{
${ }^{6}$ Fattah, Landasan Manajemen Pendidikan, h. 75.

${ }^{7}$ Bisa ditelusuri lebih lanjut dalam Saefrudin, "Pengorganisasian dalam Manajemen," Jurnal al-Hikmah Vol. 5, no. 2 (2017): h. 59.
} 
5) Pengendalian .

6) Peranan personal atau individu.

7) Motif organisasi.

8) Struktur dalam organisasi

Jika proses pengorganisasian dapat dilaksanakan sebaik dan semaksimal mungkin maka secara otomatis dapat dipastikan organisasi yang disusun akan berjalan dengan baik, dan maksimal pula. dan sesuai dengan segala kebutuhan organisasi yang akan dicapai.

\section{c) Beberapa Faktor Penentu dalam Struktur Organisasi}

Dalam tinjauan E. Kast dan James E. Rosenzweight, struktur mempunyai arti sebagai pola hubungan suatu organisasi. Struktur merupakan sebuah sistem formal hubungan kerja yang mengklasifikasi dan mengkoordinasikan tugas, pokok dan fungsi secara individual ataupun komunal untuk mencapai tujuan bersama. ${ }^{8}$

Sebagai sebuah keniscayaan dalam struktur organisasi terdapat kedudukan-posisi kerja, pembagian-penentuan pekerjaan, jenis-macam pekerjaan yang dilakukan serta hubungan antara atasan-bawahan, kelompok, komponen atau bagian, hierarki manajemen dan komunikasi.

Suatu struktur organisasi menspeksifikasi atas klasifikasi kegiatan kerja dan mengarahkan bagaimana seyogyanya fungsi atau kegiatan kerja dilakukan serta mengamati kegiatan yang berbeda-beda saling terikat. Struktur tersebut merujuk kepada jenjang hak dan kekuasaan bertindak dalam organisasi dan menampakkan relasi elegan antar individu.

Adapun menurut Stoner struktur organisasi terdapat lima item, yaitu sebagaimana berikut ini:

\footnotetext{
${ }^{8}$ Saefrudin, h. 59.
} 
a) Spesialisasi aktivitas-rutinitas, yaitu: spesifikasi atau klasifikasi wewenang yang dilaksanakan secara individual atau komunal dalam suatu organisasi.

b) Tolak-ukur aktivitas-rutinitas, yaitu: prosedur yang dipakai dalam sebuah organisasi untuk menjamin kelayakan dalam pemanfaatan dari berbagai aktivitas-rutinitas.

c) Koordinasi aktivitas-rutinitas, merupakan sebuah langkah untuk mengintegrasikan fungsi-fungsi yang telah dipertimbangkan dan dipilih dalam suatu organisasi.

d) Sentralisasi dan desentralisasi pengambilan keputusan, mengacu pada lokasi kekuasaan pengambilan keputusan. Sentralisasi ialah proses konsentrasi wewenang dan pengambilan keputun pada tingkat atas suatu organisasi. Sedangkan desentralisasi adalah pendelegasian wewenang pada semua tingkat organisasi.

e) Ukuran unit kerja, mengacu pada jumlah pegawai dalam suatu kelompok kerja. ${ }^{9}$

\section{Metode Penelitian}

Pada penelitian ini mengiplementasikan metode penelitian dengan pendekatan kualitatif bersifat deskriptif. Dalam definisi Bodgan dan Tailor sebagaimana yang dikutip oleh Moelang menyatakan bahwa metode penelitian kualitatif adalah sebuah prosedur penelitian yang menghasilkan data deskriptif berbentuk narasi kata tertulis atau lisan atau berupa tindakan kebijakan. ${ }^{10}$

${ }^{9}$ Saefrudin, h. 59-60.

${ }^{10}$ Lexy J. Moleong, Metodologi Penelitian Kualitatif (Bandung: PT. Remaja Rosdakarya, 2017), h. 186. 
Dalam penelitian ini, peneliti mencoba menjabarkan dan mendeskripsikan markaz Bahasa Arab DLWI dalam bidang manajemen pengorganisasian. Membahas tentang pengorganisasian program-program di markaz Bahasa Arab DLWI Pamekasan mengenai siapa penggerak dan pelaksana dalam setiap rangkaian program dan pemetakan tugas sehingga membangun suatu komunikasi dan kerja sama antara satu individu dengan yang lain. Dalam hal ini, tindakan yang dilakukan peneliti adalah mewawancarai pengasuh, pengurus, Muallim, dan beberapa santri menimba ilmu di sana.

Sedangkan teknik pengumpulan data melalui wawancara dan observasi di markaz Bahasa Arab DLWI, yaitu melakukan komunikasi mubasyarah dan dialog-interaktif bersama pengajar di markaz DLWI Pamekasan serta mengamati dan meninjau segala bentuk kegiatan-kegiatan dan programprogram tersebut dilaksakanan. Dibalik itu, peneliti juga melaksanakan dokumentasi tentang markaz Arab DLWI Pameksan.

Setelah semua data telah didapatkan, melakukan analisis data via teknik analisis data deskriptif. Yang dalam pengertian Miles dan Huberman dalam Sugiyono mengungkapkan bahwa teknik analisis data dapat dilaksanakan dengan tiga langkah pokok yaitu: 1) reduksi data (data reduction), yaitu mengelompokkan, menggolongkan, memetakan, mengklasifikasikan, membuang yang tidak dibutuhkan dan mengorganisir data secara valid; 2) pemaparan data (data display), yaitu mengungkap pola-pola dan relasi yang mempunyai satu makna dan mendatangkan kemungkinan adanya penetapan sebuah konklusi atau kesimpulan; dan 3) penarikan kesimpulan atau pemeriksaan lebih lanjut atas sebuah kenenaran (conclusion drawing or verification). ${ }^{11}$

\footnotetext{
${ }^{11}$ Sugiono, Metode Penelitian Pendidikan Pendekatan Kuantitatif, Kualitatif, dan $R \& D$ (Bandung: Alfabeta, 2017), h. 333.
} 
Pada bidang ini, peneliti sowan kepada Pengasuh untuk menanyakan berbagai kegiatan program pengorganisasian di DLWI, setelah itu mendatangi pengurus menanyakan seperangkat kegiatan yang telah dilaksanakan di pondok ini dalam program pengorganisasian, belum cukup sampai di sini peneliti juga mewawancarai santri senior yang belajar di sana tentang pendapatnya mengenai menajemen program yang telah dilaksanakan. Maka kemudian mensinkronkan dengan teori yang telah diuraikan di atas.

\section{Lembaga Markaz Arab DLWI Pamekasan}

Secara eksplisit Pendidikan non-formal merupakan salah satu wadah untuk melaksanakan program-program proses belajar-mengajar dalam upaya menciptakan salah satu wahana untuk mewujudkan suasana yang mendukung dan menunjang perkembangan peserta didik atau warga belajar dalam hubungannya dengan ekplorasi khazanah keilmuan, keterampilan, kecakapan, dan kesejahteraan keluarga.

Pendidikan non-formal berorientasi pada pemenuhan kebutuhan tertentu yang sifatnya fungsional dalam konteks masa kini dan prospek ke depan, serta menyajikan pengajaran berupa kemahiran, kecakapan dan keterampilan baik dalam bentuk barang maupun jasa. ${ }^{12}$

Markaz bahasa adalah bagian dari satuan lembaga pendidikan nonformal yang mempunyai fungsi sebagai pendukung, penambahan, pelengkap ataupun pengganti dari pada pendidikan formal itu sendiri, yang sekaligus sebagai menifestasi pendidikan yang kontinu bagi segenap warga- masyarakat yang membutuhkannya. Markaz bahasa bermanfaat sebagai wahana perantara atas pendidikan formal dan dunia kerja.

Bahkan pelaksanaan kegiatan bahasa arab dalam markaz bahasa diterapkan bagi segenap lapisan masyarakat yang membutuhkan bekal

\footnotetext{
12 Mustafa Kamil, Model Pendidikan dan Pelatihan (Konsep dan Aplikasi) (Bandung: Alfabeta, 2012), h. 132.
} 
keilmuan, kemahiran, kecakapan hidup dan sikap untuk mengembangkan potensi diri, meningkatkan profesionalisme bekerja serta usaha membentuk pribadi mandiri. ${ }^{13}$

Markaz bahasa Arab merupakan wahana pelatihan bagi setiap orang yang memiliki keinginan mengembangkan potensi kemahiran berbahasa baik dari segi sikap ataupun pengetahuan warga-masyarakat untuk memenuhi kebutuhan fungsional mereka baik dalam orientasi profesionlitas atau semata-mata menambah khazanah keilmuan dan keterapilan berbahasa. Dalam dunia markaz bahasa terdapat manajemen pengorganisasian upaya membentuk relasi kerja antar perorangan dalam lembaga tersebut agar mencapai cita-cita dan tujuan yang ditargetkan. ${ }^{14}$

\section{Pembahasan}

Manajemen pengorganisasian markaz bahasa Arab Darul Lughah Waddirasat Al-Islamiyah (DLWI) Pamekasan. Berdasarkan observasi dan wawancara yang dilakukan oleh peneliti terhadap salah satu pengurus sekaligus ustadz dimarkaz tersebut (ustadz FH) bahwa proses atau langkah manajemen pengorganisasian di Markaz bahasa Arab Darul Lughah Waddirasat Al-Islamiyah (DLWI) dapat dijabarkan sebagai berikut :

a. Tujuan markaz bahasa Arab DLWI adalah untuk memenuhi kebutuhan masyarakat terhadap pembelajaran bahasa Arab komunikatif yang berarti bahwa adanya markaz tersebut hadir untuk menyelesaikan masalah yang terjadi di masyarakat bahwa bahasa Arab dikenal dengan bahasa ibadah saja dan tidak bisa diaplikasikan sebagai bahasa komunikasi dan hal ini

\footnotetext{
${ }^{13}$ Siswanto, Pengembangan Kurikulum (Pelatihan Pendidikan Nonformal) (Semarang: Unnes Press, 2011), h. 53.

${ }^{14}$ Lihat dalam artikel yang ditulis M. Hasyim, "Andragogi dalam Pembelajaran Bahasa Arab," Arabiyat: Jurnal Pendidikan Bahasa Arab dan Kebahasaaraban Vol. 2, no. 1 (2015): h. 35, https://doi.org/10.15408/a.v2i1.1512.
} 
dibantah dengan adanya markaz bahasa Arab tersebut. Setiap program di markaz tersebut diarahkan kepada bahasa Arab yang komunikatif yang diharapkan nanti ketika para santri kembali ke masyarakat bisa mengaplikasikan bahasa Arab di masyarakat.

b. Penentuan dan pengelompokan program pembelajaran di markaz bahasa Arab DLWI berdasarkan tingkatan setiap santri yaitu pada tingkatan ibtida' mutawassith dan mutaqoddim.Pada pembelajaran di ibtida' terfokus pada perbendaharaan mufrodat.Pada tingkatan mutawassith terfokus pada perangkaian kata dan pratek mukalamah berdasarkan pada mufrodat yang telah didapat pada tingkatan ibtida'.Sedang di tingkatan mutaqoddim terfokus pada insya' dan tentunya mukalamah.Selain program pembelajaran yang diberikan dikelas terdapat program yang diadakan disebuah ruangan yang harus diikuti oleh setiap tingkatan baik ibtida' mutawassith dan mutaqoddim yaitu diistilahkan dengan "Barnamij Usbu'iyah".Yang diisi oleh para santri dari tingkatan mutaqoddim dan mutawassith secara bergantian setiap minggu.

c. Delegasi wewenang dengan memberikan tanggung jawab kepada setiap asatidz dimarkaz tersebut. Pengasuh sebagai general manager di markaz tersebut hanya sebagai pengawas dan memberikan legalisasi terhadap keputusan forum yang disetujui oleh ketua pengurus.Dan pembagian tugas diserhkan secara tertulis dalam sebuah struktur. Yang menurut syafarudin dalam bukunya bahwasanya pemberian wewenang dalam organisasi akan berpengaruh terhadap keberhasilan dan kegagalan dalam pelaksanaan tanggung jawab. ${ }^{15}$

d. Rentang kendali atau penetapan jumlah asatidz berdasarkan pada tingkatan yang ada di markaz tersebut yaitu pada tingkatan ibtida' di sediakan 5

${ }^{15}$ Syafarudin, Manajemen Organisasi Pendidikan (Medan: Perdana Publishing, 
asatidz 4orang untuk mengajar 4 maharoh dan 1 orang unuk menerima setoran mufrodat juga sekaligus menjadi musrif. Tiap ustadz rata-rata adalah para santri yang sudah lama tinggal dimarkaz tersebut dan sedang menempuh pendidikan S1 di kampus tertentu dan jurusan bahasa Arab.Serta mayoritas asatidz di markaz tersebut adalah alumni pesantren.

e. Struktur organisasi di markaz bahasa bahasa Arab DLWI merupakan struktur yang sudah terbilang mapan dan terorganisir. Tanggung jawab dan tugas setiap anggota ditentukan oleh jabatan yang tercantum dalam struktur. Jadi setiap individu tidak boleh melenceng dari tugas tanggung jawab tersebut dan jika terjadi penyalahgunaan wewenang maka pengasuh akan menegur langsung yang bersangkutan.

Struktur yang tercantum di markaz tersebut adalah sebagaimana dalam bagan berikut ini :

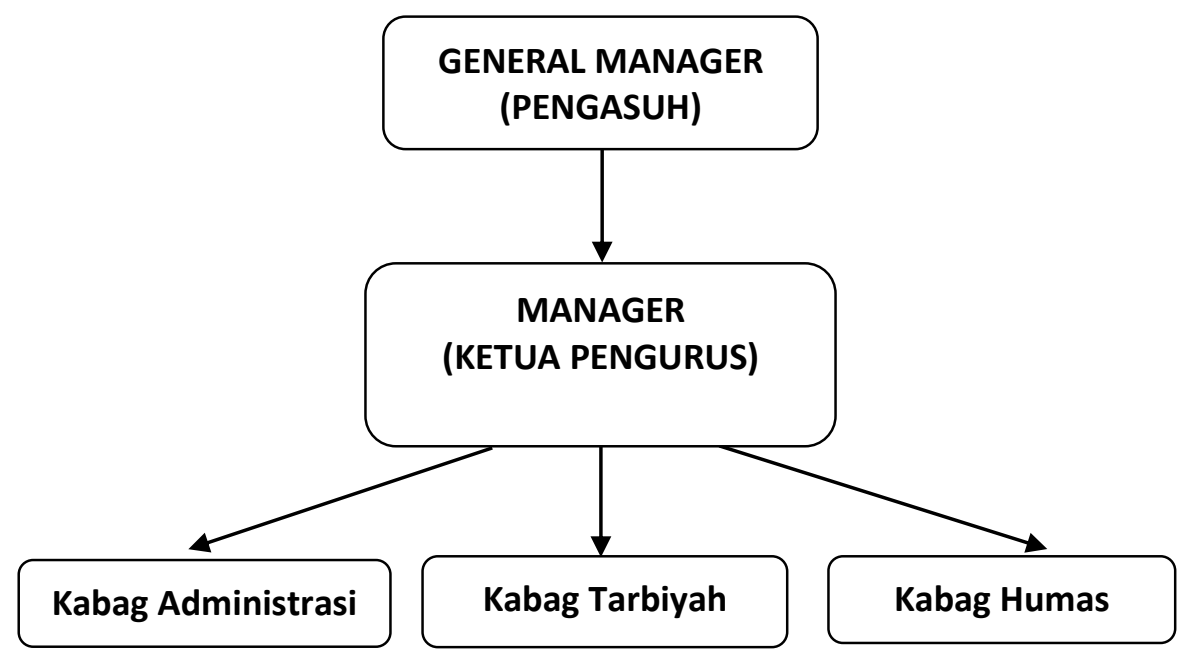

Bagan 1 -Sturktur PP. Darul Lughah Waddirasat Islamiyah

Markaz bahasa Arab darul lughah waddirasat al-islamiyah merupakan lembaga kursus yang khusus mengembangkan kemampuan berbahasa para santrinya berdasarkan teori komunikatif, dengan demikian para santri diharapkan mampu berbahasa Arab secara aktif dalam keseharian mereka. 


\section{Tujuan Program Kursus Bahasa Arab di PP. DLWI}

Tujuan program kursus bahasa Arab PP. DLWI adalah terciptanya generasi bahasa Arab yang mumpuni, serta mampu bersaing dalam kancah nasional maupun internasional, dan adanya program kursus tersebut lebih pada menjawab permintaan masyarakat yang resah karena bahasa arab hanya dianggap sebagai bahasa al-Qur'an saja. Tujuan ini selaras dengan apa yang diutarakan oleh Suharsimi Arikunto, bahwa tujuan terbentuknya sebuah lembaga pendidikan setidaknya terdapat tujuan pokok; yaitu:

a. Tujuan pendidikan nasional yaitu tujuan yang hendak dicapai dengan adanya upaya pendidikan secara menyeluruh. Tujuan ini termasuk tujuan umum yang sudah disahkan oleh pemerintah melalui GBHN.

b. Tujuan institusional adalah tujuan tujuan yang dirumuskan dan hendak dicapai oleh suatu lembaga pendidikan dan tujuan ini bersifat khusus yang disesuaikan dengan apa yang akan dicapai oleh lembaga tertentu.

c. Tujuan kurikuler adalah tujuan pendidikan yang akan dicapai dalam suatu bidang studi tertentu. Dengan kata lain tujuan ini adalah suatu yang hendak dicapai melalui tiap bidang studi yang diajarkan. ${ }^{16}$

Dalam hal ini PP. DLWI merumuskan tujuan program yang hendak dicapai adalah termasuk dalam tujuan institusional karena dalam perumusan tersebut tidak terdapat adanya campur tangan pemerintah karena sedari awal lembaga ini termasuk lembaga yang independent. Meskipun demikian lembaga kursus tersebut tidak mengesampingkan adanya tujuan pendidikan nasional sebagaimana tercantum dalam GBHN, namun dalam praktiknya lembaga tersebut lebih cendrung pada pencapaian

\footnotetext{
${ }^{16}$ Suharsimi Arikunto, Prosedur Penelitian Suatu Pendekatan Praktek (Bandung: Bina Aksara, 2002), h. 14-16.
} 
tujuan yang telah dirumuskan secar internal dan fokus hanya untuk menjawab tuntutan dari masyarakat di atas.

\section{Penentuan Pengelompokan Peserta Kursus di PP. DLWI}

Pengelompokan peserta didik dalam pembelajaran sangatlah diperlukan dalam hal ini karena setiap individu dalam sebuah kelompok belajar mempunyai perbedaan baik dari segi kemampuan, bakat dan latar belakang. Menurut Imron pengelompokkan adalah penggolongan peserta didik berdasarkan karakteristik mereka masing-masing. dengan mengkondisikan peserta didik demikian, maka peserta didik akan lebih mudah dalam mendapatkan pelayanan yang sama. Dengan pengelompokan yang demikian diharapkan kegiatan belajar mengajar berjalan denga efektif dan efisien serta tujuan pembelajaran bisa tercapai secara maksimal. ${ }^{17}$

Menurut Yeager, dalam mengelompokkan peserta didik didasarkan pada dua fungsi yaitu fungsi integarasi dan fungsi perbedaan. Fungsi integarasi funsi ini didasarkan pada kesamaan dari peserta didik, pengelompokan semacam ini berdasarkan jenis kelamin, umur, dan lainlain. Fungsi perbedaan yaitu pengelompokan peserta didik berdasarkan pada perbedaan-perbedaan individu yang dimiliki oleh peserta didik misalnya minat, bakat, kemampuan dan lain-lain. ${ }^{18}$

Berdasarkan observasi yang dilakukan oleh peneliti bahwa dalam hal pengelompokan peserta didik PP. DLWI didasarkan pada pengelompokan peserta didik dengan fungsi perbedaan. Hal ini terlihat pada pengelompokan santri didasarkan pada kemampuan berbahasa mereka dari situ muncul tingkatan-tingkatan yaitu tingkatan Ibtida' tingkatan mutawassith, dan tingkatan mutaqoddim.

\footnotetext{
${ }^{17}$ Ali Imron, Manajemen Peserta Didik Berbasis Sekolah (Jakarta: Bumi Aksara,
} 2015), h. 97.

${ }^{18}$ Imron, h. 112. 


\section{Delegasi Wewenang PP. DLWI}

Delegasi wewenang dengan memberikan tanggung jawab kepada setiap asatidz dimarkaz tersebut. Pengasuh sebagai general manager di markaz tersebut hanya sebagai pengawas dan memberikan legalisasi terhadap keputusan forum yang disetujui oleh ketua pengurus. Dan pembagian tugas diserhkan secara tertulis dalam sebuah struktur. Yang menurut Saefrudin dalam tulisannya bahwasanya pemberian wewenang dalam organisasi akan berpengaruh terhadap keberhasilan dan kegagalan dalam pelaksanaan tanggung jawab. ${ }^{19}$ Hal ini juga dikuatkan oleh Hasibuan bahwa dalam pengorganisasian suatu proses pembentukan struktur dengan bagian-bagian yang diientegrasikan sedemikian rupa sehingga terdapat hubungan satu sama lain terikat itu adalah hal paling urgen. ${ }^{20}$

\section{Rentang Kendali (Span of Control) PP. DLWI}

Rentang kendali (span of control) adalah jumlah pegawai atau bawahan yang dapat dikendalikan secara efektif oleh seorang manajer atau supervisor pada satu waktu. ${ }^{21}$ Di PP. DLWI, kedudukan pegawai sama dengan Asatidz sedangkan yang berposisi sebagai manajer atau superviser adalah pengasuh, maka rentang kendali atau penetapan jumlah asatidz di pondok ini, berdasarkan pada tingkatan yang ada di markaz tersebut yaitu pada tingkatan ibtida' disediakan 5 asatidz 4 orang untuk mengajar 4 maharoh dan 1 orang unuk menerima setoran mufrodat juga sekaligus menjadi musrif. Tiap ustadz rata-rata adalah para santri yang sudah lama

${ }^{19}$ Alvi Dyah Rahmawati, "Manajemen Pengorganisasian Program Kursus Bahasa Arab di Pare Kediri," Arabi: Journal of Arabic Studies Vol. 3, no. 1 (2018): h. 3, https://doi.org/10.24865/ajas.v3i1.71.

${ }^{20}$ Hasibuan, Dasar-Dasar Manajemen (Jakarta: Bumi Aksara, 2005).

${ }^{21}$ Rola Yona Anto, "Pengaruh Struktur Organisasi, Rentang Kendali dan Budaya Organisasi Terhadap Kinerja Pegawai Badan Penyelenggaraan Pelayanan Perizinan Terpadu Kota Kendari," e-JKPP Vol. 1, no. 2 (2015), http://jurnal.ubl.ac.id/index.php/ejkpp/article/view/596. 
tinggal dimarkaz tersebut dan sedang menempuh pendidikan $\mathrm{S} 1$ di kampus tertentu dan jurusan bahasa Arab. Serta mayoritas asatidz di markaz tersebut adalah alumni pesantren.

\section{Struktur organisasi PP. Darul Lughah Waddirasat Islamiyah Palengaan Pamekasan}

Struktur organisasi di Markaz Bahasa Arab DLWI adalah sebagai berikut: Pengasuh pondok pesantren berperan sebagai pemegang kekuasaan tertinggi dalam lembaga tersebut. Pengasuh yang berperan sebagai manager di lembaga tersebut mempunyai wewenang dalam membentuk divisi-divisi yang ada dibawah kepemimpinannya di lembaga markaz Darul Lughah waddirasah Al-Islamiyah (DLWI), misalnya membentuk divisi-divisi yang bertugas menjalankan tugas-tugas yang ditetapkan.

Dalam sistem pengorganisasian lembaga tersebut terdapat beberapa divisi seperti divisi ta'limiyah yang mengatur jalannya ta'lim atau pemebelajaran. Divisi kebahasaan yang menangani masalah bahasa. Bendahara yang menangani keuangan pondok. Sekretaris yang berperan dalam mengatur pencatatan data pondok dan penerimaan santri baru. Divisi keamanan yang menangani pelanggaran santri, baik melanggar dalam peratura-peraturan yang bersifat ubudiyah dan kebahasaan atau pelanggaran menggunakan bahasa selain bahasa Arab. Divisi kebersihan yang bertugas mengatur keasrian pondok dan penetapan jadwal piket santri, serta divisi ubudiyah yang menangani urusan peribadatan santri.

Hal tersebut sesuai dengan apa yang dipaparkan oleh Hasibuan. Dia mengatakan bahawa Organisasi bermakna sebagai sebuah gambaran atau skema yang memilili garis-garis dan menunjukkan perintah atau kedudukan anggota serta hubungan antar individu yang telah ditetapkan. ${ }^{22}$

\footnotetext{
${ }^{22}$ Hasibuan, Dasar-Dasar Manajemen.
} 
Tipe organisasi yang diterapkan di PP. DLWI mengadopsi tipe organisasi lini yaitu salah satu bentuk organisasi yang manajer puncaknya memegang semua wewenang, meliputi segala keputusan dan tanggung jawab bertumpu pada satu kendali, dan setiap anggotanya hanya mengenal satu pinpinan langsung yang membawahinya. ${ }^{23}$

\section{E. Simpulan}

Dalam penerapan manajemen pengorganisasian markaz bahasa Arab Darul Lughah Waddirasat Islamiyah mengadopsi tipe organisasi lini. Organisasi ini menerapkan pengelompokan program berdasarkan jenjang masing-masing tingkatan. Dalam penyerahan wewenang dan tanggung jawab didasarkan pada tugas pokok yang terdapat dalam struktur organisasi. Jadi, para anggota organisasi tidak sewenang-wenang dalam menjalankan tugas pokoknya. Penyerahan tugas ini tidak serta merta diberikan kepada sembarang orang, akan tetapi melalui sistem kualifikasi yang ketat.

${ }^{23}$ G. Saydam, Soal-Jawab Manajemen dan Kepemimpinan (Jakarta: Penerbit Djambatan, 1993), h. 92. 


\section{Daftar Pustaka}

Al-Hawary, dan Sayyid Mahmud. Idarah Al-Usus wa Ushul Al-Ilmiyah. Kairo: Darul Kutub Al-Ilmiyah, 1976.

Anto, Rola Yona. "Pengaruh Struktur Organisasi, Rentang Kendali dan Budaya Organisasi Terhadap Kinerja Pegawai Badan Penyelenggaraan Pelayanan Perizinan Terpadu Kota Kendari." $e$ JKPP Vol. 1, no. 2 (2015).

http://jurnal.ubl.ac.id/index.php/ejkpp/article/view/596.

Arikunto, Suharsimi. Prosedur Penelitian Suatu Pendekatan Praktek. Bandung: Bina Aksara, 2002.

Fattah, Nanang. Landasan Manajemen Pendidikan. Bandung: Remaja Rosdakarya, 2004.

G. Saydam. Soal-Jawab Manajemen dan Kepemimpinan. Jakarta: Penerbit Djambatan, 1993.

Hasibuan. Dasar-Dasar Manajemen. Jakarta: Bumi Aksara, 2005.

Hasibuan, Malayu S.P. Manajemen: Dasar, Pengertian, dan Masalah. Jakarta: CV. Haji Mas Agung, 1990.

Hasyim, M. "Andragogi dalam Pembelajaran Bahasa Arab.” Arabiyat: Jurnal Pendidikan Bahasa Arab dan Kebahasaaraban Vol. 2, no. 1 (2015). https://doi.org/10.15408/a.v2i1.1512.

Imron, Ali. Manajemen Peserta Didik Berbasis Sekolah. Jakarta: Bumi Aksara, 2015.

Islam, Asep Muhammad Saepul. "Faktor Demotivasi Pembelajaran Bahasa Arab dalam Perspektif Siswa Madrasah." Arabiyat: Jurnal

Pendidikan Bahasa Arab dan Kebahasaaraban Vol. 02, no. 1 (2015).

Kamil, Mustafa. Model Pendidikan dan Pelatihan (Konsep dan Aplikasi). Bandung: Alfabeta, 2012.

Moleong, Lexy J. Metodologi Penelitian Kualitatif. Bandung: PT. Remaja Rosdakarya, 2017.

Rahmawati, Alvi Dyah. "Manajemen Pengorganisasian Program Kursus Bahasa Arab di Pare Kediri." Arabi: Journal of Arabic Studies Vol. 3, no. 1 (2018). https://doi.org/10.24865/ajas.v3i1.71.

Saefrudin. "Pengorganisasian dalam Manajemen." Jurnal al-Hikmah Vol. 5, no. 2 (2017).

Siswanto. Pengembangan Kurikulum (Pelatihan Pendidikan Nonformal).

Semarang: Unnes Press, 2011.

Sugiono. Metode Penelitian Pendidikan Pendekatan Kuantitatif, Kualitatif, dan $R \& D$. Bandung: Alfabeta, 2017.

Syafarudin. Manajemen Organisasi Pendidikan. Medan: Perdana Publishing, 2015. 